\title{
P05.62. Clinical identification of patient propensities to choose integrative medicine for back pain: results from the SPICER project
}

\author{
M Aickin ${ }^{1}$, H Tick ${ }^{1 *}$, A McCaffery², C Ritenbaugh ${ }^{1}$, G Pugh², D Himick² \\ From International Research Congress on Integrative Medicine and Health 2012 \\ Portland, Oregon, USA. 15-18 May 2012
}

\section{Purpose}

Back pain is one of the major sources of disability in the US, but existing studies often have a restricted focus, leaving many patients unstudied.. The SPICER project is designed to assess the effect of integrative medical care in a mixed integrative/conventional clinic, using only existing electronic medical records, without any patient exclusions. This report will present information on which patient characteristics are good candidates to be used for adjustment or matching to reduce treatment selection bias.

\section{Methods}

All diagnoses, visits, services, procedures, claims, and medications were extracted on 8,000 back pain patients from 2002 to 2009. Integrative medicine services were acupuncture, bodywork (including massage), and chiropractic. Event-stream data methods were used to construct analysis datasets containing potential matching factors: gender, age, year of first visit, comorbidities, combinations of 7 categories of back pain at first diagnosis, and use of integrative medicine prior to diagnosis of back pain.

\section{Results}

The volume of results is considerable, because no patients were excluded for having a complex medical record. In general, selection of integrative medicine for back pain was positively related to being female, being older, having used it before back pain diagnosis (thus prior acupuncture use is strongly related to its later use, and similarly for the other treatments), strongly related

'University of Arizona, Tucson, USA

Full list of author information is available at the end of the article to the complexity of the initial back pain diagnosis, and tending to decrease over calendar time.

\section{Conclusion}

Identification of clinical variables that contribute to the propensity to use integrative medicine is vitally important for non-intervention research from medical records. All techniques for reducing treatment selection bias depend on them. The results reported here show that there is an adequate battery of matching factors that are in concert strongly related to choice of therapy.

\section{Author details}

${ }^{1}$ University of Arizona, Tucson, USA. ${ }^{2}$ Marino Centers for Integrative Health, Boston, USA

Published: 12 June 2012

\section{doi:10.1186/1472-6882-12-S1-P422}

Cite this article as: Aickin et al:: P05.62. Clinical identification of patient propensities to choose integrative medicine for back pain: results from the SPICER project. BMC Complementary and Alternative Medicine 201212 (Suppl 1):P422.

Submit your next manuscript to BioMed Central and take full advantage of:

- Convenient online submission

- Thorough peer review

- No space constraints or color figure charges

- Immediate publication on acceptance

- Inclusion in PubMed, CAS, Scopus and Google Scholar

- Research which is freely available for redistribution 